Stamceller fra eget hjerte for behandling av hjertesykdom?

\section{I mus kan celler fra epikard trans- differensiere til hjertemuskelcel- ler, vandre inn og reparere et hjerteinfarkt.}

Det meste av kunnskapen om stamceller og celleutvikling kommer fra dyreforsøk og in vitro-studier. Kan kunnskapen få klinisk anvendelse hos mennesker?

Embryonale stamceller er pluripotente og kan gi opphav til alle typer vev. Det samme gjelder induserte pluripotente stamceller (iPSC), som kan lages fra vanlige kroppsceller. Våre egne multipotente stamceller $\mathrm{i}$ beinmargen har i mange år vært $\mathrm{i}$ klinisk bruk i behandling av bl.a. kreftsykdommer. Dessuten er patologiske stamceller blitt reparert ved at friskt, «helbredende» gen er satt inn i stamcellegenomet ved hjelp av virale vektorer. Men det er mange mulige bivirkninger ved slik genterapi, bl.a. er det risiko for kreftutvikling.

Ville det være bedre å satse på umodne celler i de organene som skal regenerere etter skade? I en studie som nylig er publisert i Nature, er det i en musemodell vist at celler fra epikard kan transdifferensiere til hjertemuskelceller og vandre inn og reparere et hjerteinfarkt (1).
- Kunnskapen om induserte pluripotente stamceller er et viktig gjennombrudd, sier professor Joel Glover, leder av Norsk stamcellesenter. - For det første viser den at ferdig differensierte celler kan «spoles» tilbake til en tilstand der de kan uttrykke nær sagt alle gener. For det annet gir kunnskapen muligheter til å bruke pasientens egne celler til å danne en hvilken som helst annen type celle til behandling av skader eller sykdom, der autologe, transplanterte celler ikke blir forkastet.

Denne studien viser at en celletransformasjon kan skje i hjertet in vivo, uten behandling av cellene in vitro. Det er åpenbare fordeler ved å benytte seg av en tilsynelatende naturlig prosess utløst under et hjerteinfarkt. Dersom man kan utvikle metoder for å styre prosessen, ville man kunne unngå risikoen forbundet med høsting, manipulering og implantering av stamceller. Det gjenstår å se om prosedyren er gjennomførbar hos mennesker og om liknende transdifferensieringsmetoder kan brukes i andre organer, sier Glover.

\section{Haakon B. Benestad}

h.b.benestad@medisin.uio.no

Universitetet i Oslo

\section{Litteratur}

1. Smart N, Bollini S, Dubé KN et al. De novo cardiomyocytes from within the activated adult heart after injury. Nature 2011; 474: 640-4.

\title{
Antibiotikabruk uten resept
}

\section{Bruk av antibiotika uten at de er forskrevet av lege varierer sterkt mellom ulike regioner. Enkelte steder skjer all bruk utenfor sykehus uten resept.}

Det viste en gjennomgang av 117 studier, hvorav 35 befolkningsstudier, fra perioden 1970-2009 (1). Man fant kun to befolkningsstudier fra Afrika, men disse viste at $100 \%$ av antibiotika brukt utenfor sykehus ikke var forskrevet av lege. Befolkningsstudiene for de ulike regionene viste at Asia hadde nest høyest andel av antibiotikabruk uten legeforskrivning med $58 \%$, så kom Midtøsten med $39 \%$, så Sør-Amerika med $25 \%$ og Mellom-Amerika og Karibia med 19\%. I Øst-Europa skjedde $30 \%$ av antibiotikabruken utenfor sykehus uten anvising fra lege, i Sør-Europa 19\%, i Nord-Europa bare 3\%. Man fant ingen relevante studier fra NordAmerika, men all antibiotika er normalt reseptbelagt der.

I 13 av studiene unders $ø$ kte man i predefinerte simulerte situasjoner apotekansattes villighet til å selge antibiotika mot oppgitte plager. Det var ingen tidsmessig eller geografisk trend, men apotekansatte solgte ofte uadekvate antibiotika. Tuberkulostatika mot vanlige bakterielle infeksjoner og antituberkuløs monoterapi var vanlig.

Fra tidligere forskning vet man at i en rekke fattige land er mange friske kolonisert med multiresistente bakterier. De antimikrobielle midlene man har tilgjengelig i disse landene, har ofte manglende effekt mot de multiresistente bakteriene.

Forfatterne konkluderer med at den hyppige bruken av antibiotika uten legeforskrivning i land utenfor Nord-Europa og Nord-Amerika er en viktig faktor å ta med $\mathrm{i}$ kampen for å redusere antibiotikaresistens.

\section{Øyunn Holen}

oeyhole@online.no

Infeksjonsmedisinsk avdeling

Oslo universitetssykehus, Ullevål

\section{Litteratur}

1. Morgan D, Okeke IN, Laxminarayan R et al. Nonprescription antimicrobial use worldwide: a systematic review. Lancet Infect Dis 2011; 11: 692-701.

\section{Svakheter i vurdering av søknader om forskningsmidler}

\author{
Tildeling av prosjektmidler fra \\ det australske forskningsrådet \\ for helse og medisin er kostnads- \\ krevende og noe tilfeldig.
}

Det er gjort lite forskning på fagfellevurderingen av søknader om forskningsmidler. Nå har australske forskere studert evalueringsprosessen i det australske forskningsrådet for helse og medisin (1).

Søknadene ble vurdert av paneler med 7-13 fagfeller i hvert panel. Av alle søknadene som ble sendt inn i 2009, fikk $23 \%$ $(n=620)$ støtte. Ved å bruke en «bootstrap»modell der nye skårer ble estimert ut fra en liten endring i panelet, f.eks. at ett medlems skår ble erstattet av et annet medlems skår, ble søknadene kategorisert i tre tildelingsgrupper: de som alltid, av og til eller aldri ble støttet ut fra de nye skåringene. Kun $9 \%$ av søknadene kom i kategorien «alltid» tildelt, $29 \%$ kom i «av og til» og $61 \%$ kom $i$ «aldri». Større paneler var mer kostnadskrevende enn små, men viste også høyere reliabilitet.

- Resultatene i denne studien er ikke overraskende. Alle som arbeider med evaluering av forskningssøknader, vet at eksperter kan vurdere søknadene forskjellig, noe som kan være avgjørende for om det gis støtte. Likevel mener de fleste av oss at bruk av eksperter og kvalifisert skjønn er det beste vi har, sier dekan Stig A. Slørdahl ved Det medisinske fakultet ved Norges teknisk-naturvitenskapelige universitet. Han er medlem i divisjonsstyret for vitenskap i Norges forskningsråd.

- I Norden har vi erfaringsutveksling mellom landene for hele tiden å forbedre søknadsprosedyrene. I Finland har man sett på hvordan to ulike paneler vurderte de samme søknadene, som ble klassifisert på en skala fra 1 til 6 . Bare et mindretall av søknadene fikk samme karakter fra begge panelene. Vi må være åpne for å endre rutinene for å sikre at de beste søknadene blir valgt ut. Det er ikke vanskelig å være enig med forfatterne $i$ at vi trenger mer forskning på området, sier Slørdahl.

\section{Trine B. Haugen \\ trine.b.haugen@hf.hio.no \\ Tidsskriftet}

Litteratur

1. Graves N, Barnett AG, Clarke P. Funding grant proposals for scientific research: retrospective analysis of scores by members of grant review panel. BMJ 2011; 343: d4797. 